\title{
Anesthetic Management of a Child with Cerebro-Oculo-Facio-Skeletal Syndrome
}

\section{Serebro-Okülo-Fasiyo-Skeletal Sendromlu Çocukta Anestezi Yönetimi}

\begin{abstract}
Cerebro-oculo-facio-skeletal syndrome (COFS, Pena-Shokeir syndrome Type II, Cockayne syndrome Type II) is a rare progressive syndrome with autosomal recessive transition that may cause death in childhood.

We aimed to present the anesthesia management in congenital cataract surgery in a patient with COFS in the present study.

Keywords: General anesthesia, rare disease, pediatrics, Pena-Shokeir syndrome Type II

öz

Serebro-okülo-fasiyo-skeletal sendrom (COFS, Pena-Shokeir Syndrome Type II, Cockayne Syndrome Type II); çocukluk çağında ölümlere neden olabilen otozomal resesif geçişli, nadir görülen progresif bir sendromdur.

Bu olgu sunumu ile COFS tanılı hastamızda konjenital katarakt cerrahisi için anestezi yönetiminin sunulması amaçlanmıştır.
\end{abstract}

Anahtar kelimeler: Genel anestezi, nadir hastalık, pediatri, Pena-Shokeir sendromu Tip II
Alındığı tarih: 21.11 .2018

Kabul tarihi: 19.12.2018

Yayın tarihi: 31.01 .2019

Alev Şaylan

SBÜ Kartal Dr. Lütfi Kırdar Eğitim ve Araştırma Hastanesi, Anesteziyoloji ve Reanimasyon Kliniği, İstanbul, Türkiye alevdr@hotmail.com ORCID: 0000-0002-3261-1004

N. Çelebi 0000-0001-7472-6275

Ö. Canbay 0000-0001-7645-4947

Hacettepe Üniversitesi Tıp Fakültesi, Anesteziyoloji ve Reanimasyon Anabilim Dalı, Ankara, Türkiye

\section{INTRODUCTION}

Cerebro-oculo-facio-skeletal syndrome (COFS, PenaShokeir syndrome Type II, Cockayne syndrome Type II) is a rare progressive syndrome with an autosomal recessive transmission that may cause death in childhood.

The syndrome has many components such as facial dysmorphism, micrognathia, microcephaly, microphthalmia, cataract, blepharophimosis, kyphoscoliosis, hypotonia, hyporeflexia, arthrogryposis, generalized osteoporosis, congenital flexion contractures, growth retardation, convulsion, severe mental retardation, and progressive degeneration of the brain-spinal cord ${ }^{(1)}$. In this study, we aimed to present the anesthesia management in congenital cataract surgery in a patient with COFS.

\section{CASE PRESENTATION}

The patient, who was a 7-month-old girl weighing $4500 \mathrm{~g}$ (<3rd percentile), and $59 \mathrm{~cm}$ (<3rd percentile) in height, presented with symptoms of decreased vision in both eyes to ophthalmology outpatient clinic. Her history revealed that she was born by cesarean section (2800 grams) at the $39^{\text {th }}$ week of gestation due to non-progressive delivery and deceleration. Because she had coarse crying and unable to open her eyes widely at the age of 3 days, a general practitioner ordered a karyotype analysis. According to analysis, her karyotype was found as 46XX karyotype.

She had mental, and motor retardation, coarse crying, typical facial dysmorphic appearance, retromicrognathia, nystagmus, distinctive nose root, small and deeply located eyes, hollow palate structure, 
upper lip covering the lower lip, camptodactyly, split nipples, flexion contractor in upper and lower extremities, and rocker-bottom feet. She was diagnosed with COFS and followed-up by both pediatric genetics and pediatric cardiology departments. Transthoracic echocardiography revealed left ventricular dilatation, patent foramen ovale, patent ductus arteriosus, and first- and second-degree tricuspid valve insufficiency.

She could not follow the light and had bilateral leukocoria. She was also diagnosed with bilateral congenital cataract. Surgical treatment with bilateral lensectomy and anterior vitrectomy was scheduled. Her general condition was normal in the perioperative period. Her disease severity was classified as The American Society of Anesthesiology (ASA) grade III, her body temperature $\left(36.5^{\circ} \mathrm{C}\right)$, heart rate $\left(132 \mathrm{~min}^{-1}\right)$, respiratory rate $\left(30 \mathrm{~min}^{-1}\right)$ were within physiologic limits and she had physical symptoms of COFS. Patient's family gave informed consent for anesthesia. Departments of Pediatric Genetics and Pediatric Cardiology approved the surgery with the recommendation of subacute bacterial endocarditis prophylaxis. Preoperatively whole blood count, biochemical tests, and telecardiogram results were within normal limits Premedication was performed by using $0.05 \mathrm{mg} \mathrm{kg}^{-1}$ intravenous midazolam after proper period of fasting and intravenous hydration. Anesthesia management was initiated in the operating room following intravenous $1 \mathrm{mg} \mathrm{kg}^{-1}$ lidocaine and $2 \mathrm{mg} \mathrm{kg}^{-1}$ propofol induction. A laryngeal mask airway (LMA) no: 1 was properly inserted after oxygenation with easy mask ventilation. Endocarditis prophylaxis was administered. Intraoperatively, maintenance of anesthesia was achieved by using intravenous remifentanil $\left(0.025-0.1 \mu \mathrm{g} \mathrm{kg}^{-1} \mathrm{~min}^{-1}\right)$ and propofol infusion $\left(25-100 \mathrm{\mu g} \mathrm{kg}^{-1} \mathrm{~h}^{-1}\right)$. The basal fluid deficit was corrected with administration of $\mathrm{NaCl}$ and $5 \%$ dextrose solution during the total surgery time of 60 minutes. Intravenous paracetamol infusion (15 $\mathrm{mg} \mathrm{kg}^{-1}$ ) was administered 15 minutes before the end of surgery for pain management, and the patient was properly awakened. Her vital findings in the recovery room were within normal limits, and then she was transferred to the ward.

\section{DISCUSSION}

COFS is a rare and progressive disease, which involves the central nervous and musculoskeletal systems. Lowry reported COFS as a new syndrome in $1971^{(1)}$. Pena and Shokeir described COFS in $1974^{(2)}$. COFS has many components such as facial dysmorphism, micrognathia, microcephaly, microphthalmia, congenital cataracts, blepharophimosis, kyphoscoliosis, hypotonia, hyporeflexia, arthrogryposis, generalized osteoporosis, congenital flexion contractures, growth retardation, convulsions, severe mental retardation, and progressive degeneration of the brain and spinal cord (3). Orphanet November 2016 data reported its prevalence as $1<1.000 .000$ and 20 cases were reported worldwide (4). Recurrent aspiration pneumonia, growth, and developmental retardation, and difficulties in nutrition cause early childhood deaths ${ }^{(5)}$.

Micrognathia might cause difficult intubation, and upper airway obstruction may be seen ${ }^{(6)}$. Preservation of airway enables adequate ventilation and control of respiratory complications. We took the necessary measures preoperatively in case of a difficult airway, taking into consideration the patient's current symptoms by providing different models and dimensions of the laryngoscope set, LMA devices in different models, pediatric gum elastic bougie, pediatric video laryngoscope, and invasive airway devices. Succinylcholine administration must be avoided in these patients due to the risk of hyperkalemia Anesthetic drugs may interact with anticonvulsant drugs which are used for patients with COFS, who have an increased risk of pulmonary infection due to pulmonary hypoplasia, so an appropriate approach must be selected in anesthesia management ${ }^{(7)}$. Cardiac problems should be considered to prevent air embolism during surgery. In our patient, we were very careful due to current cardiac symptoms. Positioning must be performed with care due to secondary symptoms of spinal cord degeneration, hypotonia, hyporeflexia/areflexia, kyphoscoliosis, arthrogryposis, joint contraction, and osteoporosis. We used protective gel-type equipment for all pressure sites during positioning of our patient, and a normothermic environment was maintained during surgery. 


\section{CONCLUSION}

Rare syndromes such as COFS are special cases in terms of anesthesia management. We aimed to present our case and review the literature so as to increase awareness regarding anesthesia management in rare diseases ${ }^{(4)}$. Preservation of airway ensures adequate ventilation and control of respiratory complications. We took the necessary measures preoperatively in case of a difficult airway, taking into consideration the patient's current symptoms by providing different models and dimensions of the laryngoscope set, LMA devices in different models, pediatric gum elastic bougie, pediatric video laryngoscope, and invasiveairway devices. Succinylcholine administration must be avoided in these patients due to the risk of hyperkalemia. Anesthetic drugs may interact with anticonvulsant drugs which are used for patients with COFS, who have an increased risk of pulmonary infection due to pulmonary hypoplasia; an appropriate approach must be selected in anesthesia management ${ }^{(5)}$. Cardiac problems should be considered to prevent air embolism during surgery. In our patient, we were very careful due to current cardiac symptoms. Positioning must be performed with care due to secondary symptoms of spinal cord degeneration, hypotonia, hyporeflexia/ areflexia, kyphoscoliosis, arthrogryposis, joint contraction, and osteoporosis. We used protective geltype equipment for all pressure sides during positioning of our patient, and a normothermic environment was maintained during surgery.
As a result, proper anesthetic management is very important in especially rare cases such as COFS. In our case report, we aimed to increase awareness of anesthesia management in patients with COPS.

\section{REFERENCES}

1. Lowry RBR, McLean R, McLean DM, et al. Cataracts, microcephaly, kyphosis and limited joint movement in two siblings: a new syndrome. J Pediatr. 1971;79:282-4.

https://doi.org/10.1016/S0022-3476(71)80114-2

2. Pena SDJ, Shokeir MHK. Autosomal recessive cerebrooculo-facio-skeletal (COFS) syndrome. Clin Genet. 1974;5:285-93. https://doi.org/10.1111/j.1399-0004.1974.tb01695.x

3. Laugel V, Dalloz C, Tobias ES, et al. Cerebro-oculo-facioskeletal syndrome: three additional cases with CSB mutations, new diagnostic criteria and an approach to investigation. J Med Genet. 2008;45:564-71. https://doi.org/10.1136/jmg.2007.057141.Epub 2008 Jul 15.

4. Prevalence and incidence of rare diseases: Bibliographic data. Available from: http://www.orpha.net/orphacom/cahiers/docs/GB/Prevalence_of_rare_diseases_ by_alphabetical_list.pdf

5. Graham JM, Jr., Anyane-Yeboa K, Raams A, et al. Cerebro-oculo-facio-skeletal syndrome with a nucleotide excision-repair defect and a mutated XPD gene, with prenatal diagnosis in a triplet pregnancy. Am J Hum Genet. 2001;69:291-300. https://doi.org/10.1086/321295

6. Butler MG, Hayes BG, Hathaway MM, et al. Specific genetic diseases at risk for sedation/anesthesia complications. Anesth Analg. 2000;91:837-55. https://doi.org/10.1097/00000539-200010000-00014

7. Cladis FP. Index of syndromes and their pediatric anesthetic implications In: Peter J. Davis FPC, editor. Smith's Anesthesia for Infants and Children. $9^{\text {th }}$ ed. Elsevier; 2017. e23-e50 p. 